\title{
Socio-economical aspects of the exploitation of Termitomyces fruit bodies in central and southern Côte d'Ivoire: Raising awareness for their sustainable use
}

\author{
N'Golo Abdoulaye Koné (1)*, Kolo Yéo (1), Souleymane Konaté (1) and Karl Eduard Linsenmair (2) \\ (1) UFR-Sciences de la Nature, Station d'Écologie de LAMTO, Université Nangui Abrogoua (Côte d'Ivoire). BP 28 \\ N'Douci; (ngolo197804@yahoo.fr, koloyeo@yahoo.fr and skonate2@yahoo.fr) \\ (2) Theodor-Boveri-Institut für Biowissenschaften der Universität Würzburg (Biozentrum), Lehrstuhl Tierökologie und \\ Tropenbiologie (Zoologie III), Am Hubland, D-97074 Würzburg, Germany (ke_lins@biozentrum.uni-wuerzburg.de) \\ *Corresponding author: N'Golo Abdoulaye Koné, Station d'Écologie de LAMTO, BP 28 N'Douci, Côte d'Ivoire. \\ Phone: +225 07620384, Email ngolo197804@yahoo.fr
}

Original submitted in on 30th August 2013 Published online at www.m.elewa.org on 31 $1^{\text {st }}$ October 2013. https://dx.doi.org/10.4314/jab.v70i1.98759

\begin{abstract}
Objective: Picking fungal fruit bodies is a popular spare time occupation, as well as a source of income in many countries. In central and southern Côte d'Ivoire, fruit bodies of the genus Termitomyces are intensively harvested and sold by the local inhabitants. However, information on the dimensions of this trade and on other socio-economic aspects of the exploitation of these edible mushrooms is lacking. This study aims at (a) investigating the local populations' knowledge about Termitomyces fruit bodies, (b) examining their utilization by identifying the actors involved of their exploitation and (c) determining the factors, explaining income differences among actors of this exploitation and fructification areas. Methodology: Some 240 persons from 12 villages belonging to two sub-ethnic groups (Baoulé and Abbey) were interviewed as to their attitude towards Termitomyces, using a structured survey questionnaire. Thus, we obtained information on Termitomyces fruit bodies' availability, on indigenous knowledge and especially on the modes of utilization as well as on seasonal aspects of their trade.

Conclusions: Interviewees had a solid knowledge of edible mushrooms in general and Termitomyces in particular. Four species were recorded in the study area (Termitomyces medius, T. letestui, T. cf. eurhizus and T. fuliginosus). The latter three species were considered as edible. These mushrooms are a key source of cash income, especially for women (traders) and the farmers (harvesters). However, only one species, Termitomyces letestui, is sold through a well-established trade route. Seasonal earnings within this trade route differed among actors, visited villages and phytogeographic zones. These fungi representing a typical Non Timber Forest Products (NTFPs) are menaced by unsustainable depletion. Overharvesting is jeopardizing their persistence as well as that of their dependant termite species. Raising an awareness that prevents their incurring the "tragedy of the commons" by developing a sustainable form of harvest is an essential prerequisite for their long-term preservation.

Key words: Termitomyces; fruit bodies; Non Timber Forest Products (NTFPs); seasonal income; Sustainable use.
\end{abstract}




\section{INTRODUCTION}

Non-timber forest products (NTFPs) may be defined as all tangible animal and plant products, which can be collected from forests for subsistence and trade (Ros-Tonen et al. 1995). Several scholars considered their exploitation as a promising strategy for the long-term conservation of tropical rain forests (Anderson, 1990). Other authors, however, argued that the returns from NTFPs gathering are marginal compared to those of timber extraction and that therefore efforts should be focused on developing sustainable timber exploitation instead of, or at least along with NTFPs extraction (Browder, 1992). However, NTFPs in the tropics are the main source of livelihood of forest-dwelling communities, who rely on them for their nutrition, medicine, and raw materials for their houses, tools, and all other contents (Kusters et al. 2001). NTFPs are also the main or sole source of cash income for people living in remote rainforest areas (Ros-Tonen 2000).

The contribution of NTFPs to rural livelihoods, and the fact that their use is ecologically less destructive than timber harvesting, have supported the belief that a more intensive management of forests for such products could contribute to both local socioeconomic development as well as conservation objectives.

The harvest and trade of wild useful mushrooms are considered as economically important in many rural areas of Eastern and Central Africa - in Tanzania (Härkönen et al 1995), Burundi (Buyck \& Nzigidahera 1995), Zimbabwe (Piearce \& Sharp 2000 pers.obs.), Zambia (Pegler \& Piearce, 1980) and Congo (Thoen et al. 1973; Degreef et al. 1997). In these countries, numerous species of the genera Amanita, Termitomyces, Cantharellus are usually collected and sold by rural women. In West African

\section{MATERIAL AND METHODS}

Study area: The study was carried out in the Guinean savannah in the centre and the semi-deciduous forests in the south of Côte d'Ivoire (supporting information). The rainfall regime of this area is characterized by four seasons: a long rainy season from March to July, a short dry season in August, a short rainy season from September to October and long dry season from November to February (Pagney, 1988; Abbadie et al. countries (particularly Benin, Togo and Ghana), the cultivation of mushroom of genus Pleurotus generates income, especially for women, thereby contributing to their economic independence (van Djick et al. 2003; Apetorgbor et al. 2005). However, in spite of the high natural production of edible fungal species in these countries, their harvest and trade is qualified as an occasional activity (Yorou et al2002). In Côte d'Ivoire, mushrooms are known and consumed in many households. In rural areas where they are abundant, most people collect them for home consumption as well as for extra income. Indeed, in the Guinean savannah and the semideciduous forest areas of Côte d'Ivoire, fruit bodies of the fungal genus Termitomyces are intensively harvested and sold during their respective fructification periods. This can be observed along roadsides annually, especially along the northward highway. Still far more impressive in this regard are the rural markets in the centre and the south of the country, where huge quantities are annually offered for sale. However, despite of the threat pending upon their diversity and abundance with the current excessive deforestation and the subsequent conversion of these areas to agricultural land (FAO/UNEP, 1981), no pertinent thorough ethnomycological survey has been executed to date.

In this study, the local populations' knowledge about Termitomyces was investigated and examined their utilization by identifying the actors involved in the exploitation of these NTFPs and strived to determine the factors, which explain income differences among actors and areas. Finally, their contribution to the improvement of the livelihood of rural communities and their potential contribution to a sustainable conservation of their habitats are discussed.

2006). The mean annual precipitation is about $1200 \mathrm{~mm}$. Local inhabitants of this area belong to the autochthonous "Akan", the major ethnic group and to the "Baoulé" and "Abbey" sub-ethnic groups. "Baoulé" people have settled in villages located in the Guinean savannah whereas the sub-ethnic group of "Abbey" is found in areas located in the semi deciduous forests zone (Yao, 2001). According to this author, some endogenous Ivorian ethnic groups 
such as Malinké, Sénoufo and numerous allochtonous ethnic groups, i.e. natives of countries bordering Côte d'Ivoire such as Burkina Faso, Mali, and Guinea are also found in both zones. People from these localities mainly practice shifting cultivation, cocoa and coffee cash crop farming, and hunting, fishing and gathering.

Ethno-mycological surveys: From October to November 2009, information on Termitomyces species fructification, habitats and trade were obtained through direct surveys. These preliminary investigations were undertaken to identify the open issues of the study, refine the research hypotheses and choose villages whose surroundings ought to be visited. Pictures of the species of Termitomyces species occurring in the study area and obtained through a previously investigation (Koné et al., 2011), were used in the interviews, which aimed at determining the extent of knowledge about these fungi. The ethno-mycological and socio-economical survey was undertaken in 2010, during the main fructification periods of Termitomyces species from January to June in the study area as described by Koné et al. (2011). A survey kit (supporting information) was used to standardize information obtained from different people. The survey kit contained pictures of numerous edible and non-edible mushrooms including Termitomyces species from the studies of Koné et al., (2011); Mossebo et al., (2002) and De Kesel et al., (2002). Interviews were conducted in local languages (Baoulé and Abbey) and afterward translated into in French by local assistants selected and trained for the task. The survey kit was centered on three main issues: (1) the availability of Termitomyces fruit bodies and actors intervening in their harvest and sale, (2) the fluctuations occurring in their sale price during their respective fructification period and (3) the mean cash income of actors during a harvest and the subsequent trade campaign. In order to understand the

\section{RESULTS}

Indigenous knowledge and utilization of Termitomyces fruit bodies: Inhabitants of the study area have a solid knowledge (i.e. diversity, occurrence period, distribution and culinary) of edible mushrooms of the genus Termitomyces. Fruit bodies of this genus are the most appreciated edible mushrooms of this area. The local people call these mushrooms "termite' mushrooms" meaning "mushrooms produced or cultivated by termites". Their vernacular names are N'Glô in Baoulé and N'Kôkrô in Abbey. Three species (Termitomyces letestui, T. cf. eurhizus and T. fuliginosus) of the four occurring in the study area were recognized as edible mushrooms (Figure 1). The fourth (T. medius) was known as a Termitomyces variation of average cash income, observed among actors and between villages, a part of the questionnaire was exclusively directed towards on business harvesters encountered during the survey. An assessment of the density of termite mounds in the habitats was conducted along with the average number of fruit bodies of Termitomyces species on each mound. A total of 240 persons (20/village) made up of 138 men and 102 women, from 12 villages were interviewed. Five villages located in Guinean savannah (Oussou, Zougoussi, Ahérémou I, Ahérémou II and Singrobo) and seven others (Brimbo, Okassou, Boussoukro, Kangagnazé, Batera, Kodimanso and Bodo) located in the semideciduous forest were visited. These villages were chosen according to a virtual transect line from the centre (Guinean savannah) to the south (semi-deciduous forest) of the country. Villages were selected at random and were sufficiently distant from one another (at least $3 \mathrm{~km}$ ), to prevent exchange of information among them (van Dijk et al., 2003). Participants were volunteers who were individually interviewed to avoid biased (socially mediated) answers. The survey was conducted either in villages, on their respective markets, at the edge of the main motorways of the area (sellers) or in the field (harvesters). The average age of the participants was 27 years (12-42 years) for women and 36 years for men (1568 years).

Data analysis methods: Statistical analyses were made with the software STATISTICA version 7.1. This software was used for average comparisons using the U-test of Mann-Whitney after analyzing variability among obtained values with ANOVA of Kruskal-Wallis. These comparisons were performed for the row cash income values as variable among actors and between visited villages on one hand and for harvested fruit bodies per termite per village on the other hand.

species by only $2 \%$ of the interviewees. Only fruit bodies of $\mathrm{T}$. letestui are sold during their fructification period from February to April. Fruit bodies of this species are locally consumed in higher quantities than sold in areas close to the Guinean savanna, consumed, and sold in comparable quantities in localities situated in the semi deciduous forest. Termitomyces cf. eurhizus and T. fuliginosus are just harvested by farmers for their own consumption, since these species have never been found in large enough quantities to be traded. No difference was observed between both sub-ethnic groups regarding recognition and uses of fruit bodies of Termitomyces species. Both groups use the same resources and no 
differences in species' preference were observed. They used to take these mushrooms to replace meat and fish in sauces (i.e. palm, aubergine, gombo or tomato sauces), to be eaten with rice and pounded plantain banana, yam or cassava.
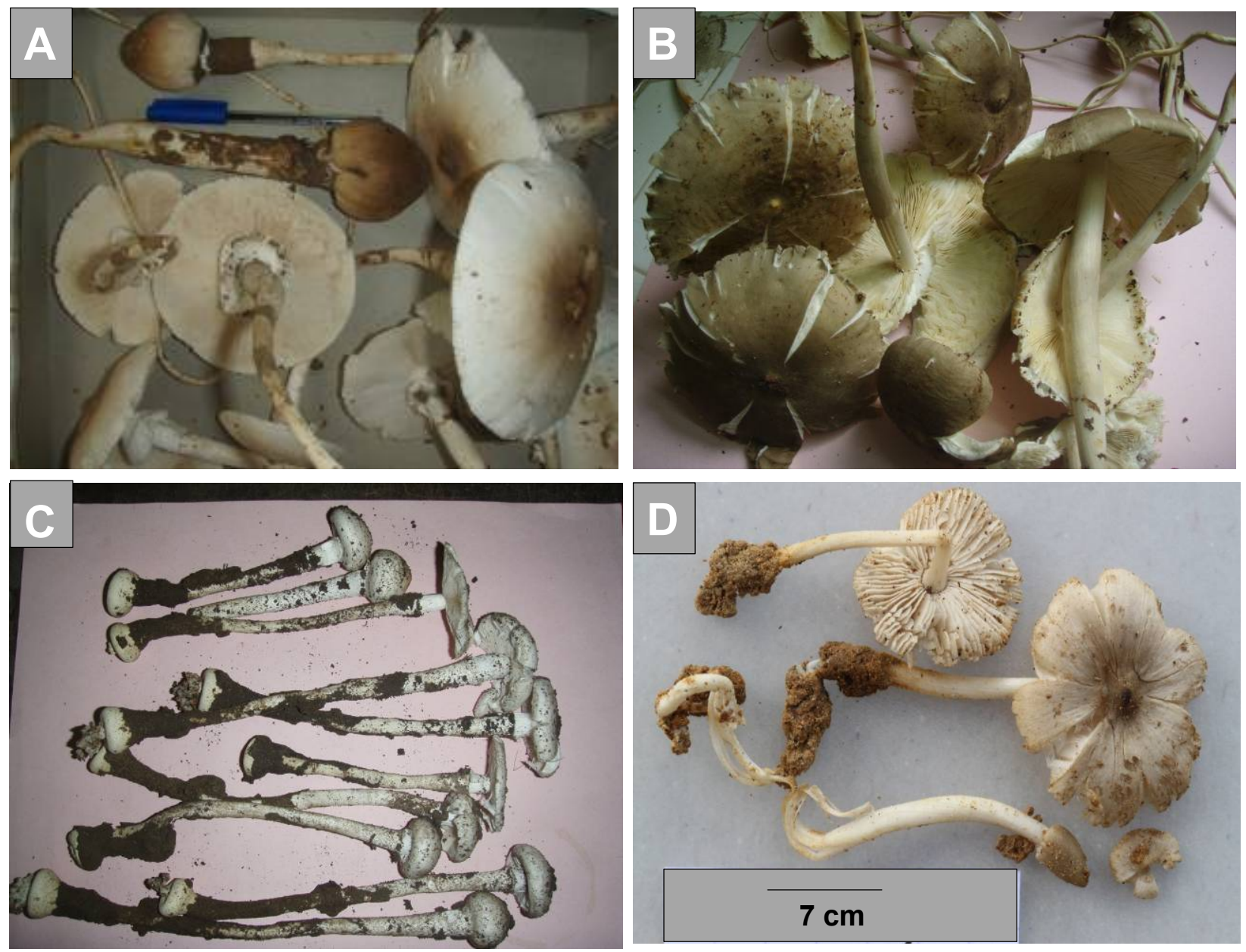

Figure 1: Termitomyces fruit bodies occurring in the study area. A: Termitomyces letestui; B: T.cf euhizus; C: T. fuliginosus and $\mathbf{D}$ : T. medius

Trade of Termitomyces fruit bodies: actors and trade route: Three main categories of actors were identified in the seasonal harvest and trade of Termitomyces fruit bodies: harvesters (including small and business harvesters), small dealers and urban wholesalers (figure 2). A total of 91 actors (38\% of the total respondents) made up of 52 business harvesters, 23 small dealers and 16 urban wholesalers were interviewed. Harvesters act as the triggers for the seasonal exploitation of Termitomyces species. They have a well-developed knowledge of the phenology and habitats of Termitomyces species. In addition, these actors have acquired a well-established cartography of those termite mounds bearing Termitomyces fruit bodies annually. Two categories of harvesters were distinguished: those visiting forest fragments near the villages, plantations (cocoa crops) and old fallows looking for personal or family consumption (small harvesters) and those harvesting high quantities of fruit bodies for sale (Business harvesters). Small harvesters are children of both sexes (9-14 years old) and women while business harvesters are exclusively men (15-38 years old). Harvesting Termitomyces fruit bodies is considered as an extra job by these actors. Business harvesters usually stormed Termitomyces habitats early in the morning to pick off fruit bodies for sale. The second category of actors consists of women (12-40 years old) representing intermediary groups of actors: rural and urban small dealers. Rural small dealers are 
intermediates between business harvesters and urban wholesalers while urban small dealers represent intermediates between urban wholesalers and consumers from big cities. Rural small dealers generally have different well-known meeting points with business harvesters in the vicinities of natural habitats of Termitomyces species. They buy fruit bodies in relatively large quantities for reselling them to urban wholesalers. An individual rural small dealer obtains her goods in general from many business harvesters. Urban small dealers are found in large cities, none was interviewed during this study. The third and last category in the trade route is formed by urban wholesalers composed of women (20-40 years old) who used to buy large quantities of fruit bodies for reselling them in big cities like Yamoussoukro, N'Zianouan and Abidjan. They also are in charge of the transportation of Termitomyces fruit bodies to urban markets. An urban wholesaler used to get her fruit bodies from many rural small dealers. As fruit bodies of fungi are rapidly, perishing, urban wholesalers used to dry the fruit bodies before transporting them to the markets. This happens when the overall quantity was too small to compensate the expenses in time and transportation fees to go to a distant market.

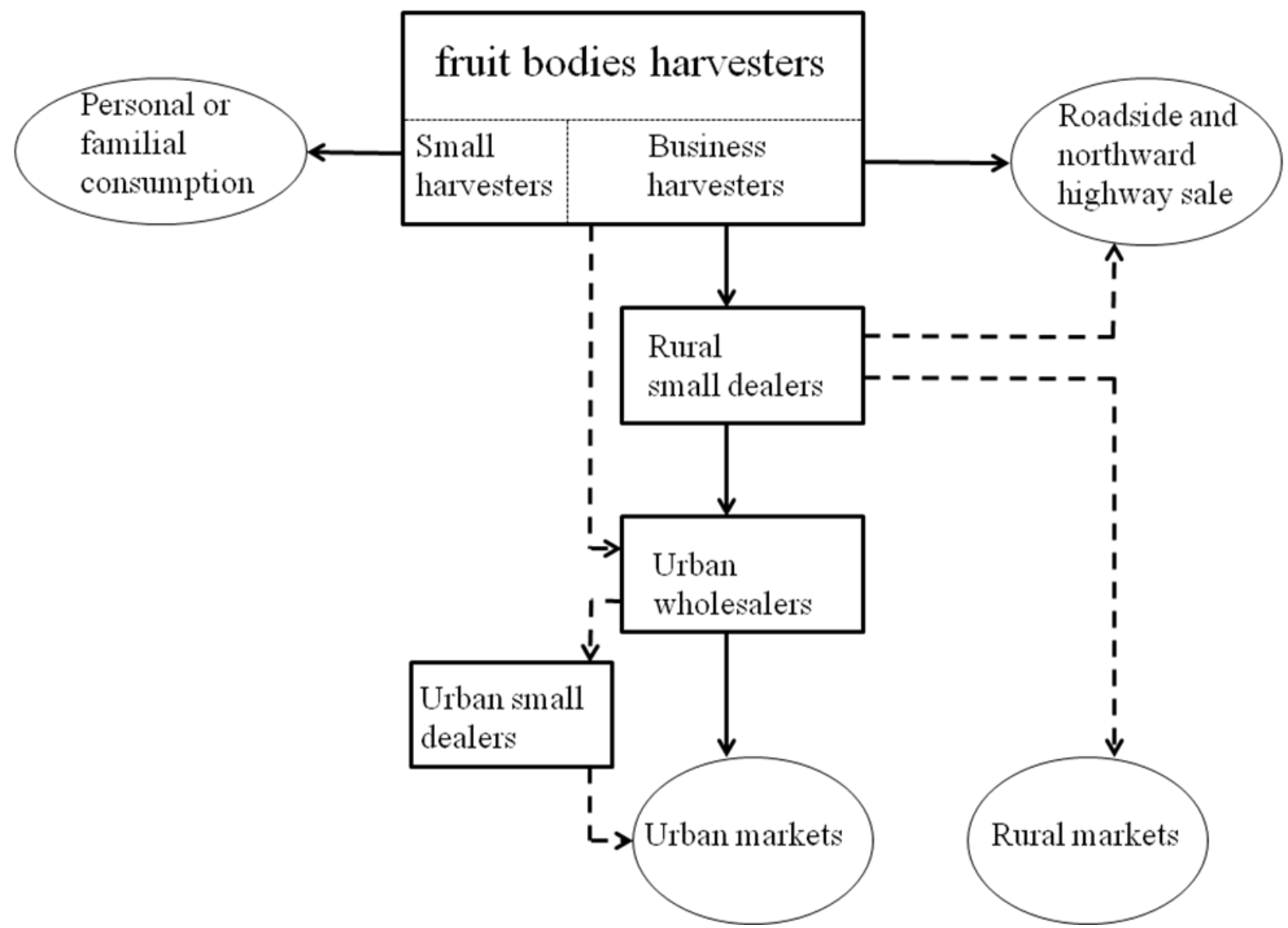

Figure 2: Harvest and commercialization trade route of Termitomyces fruit bodies in central and southern Côte d'Ivoire. One-way solid arrows indicate regular and well-established trade route with huge traded quantities of fruit bodies. Oneway broken arrows indicate the much lower traded quantities.

The full trade route (Figure 3) for the fresh fruit bodies can be completed within at least 48 hours. However, trade of dried Termitomyces fruit bodies takes place throughout the entire year. When small dealers and wholesalers are not present business harvesters usually sell the whole amount of their fruit bodies directly to passengers along roadsides and the northward highway. 

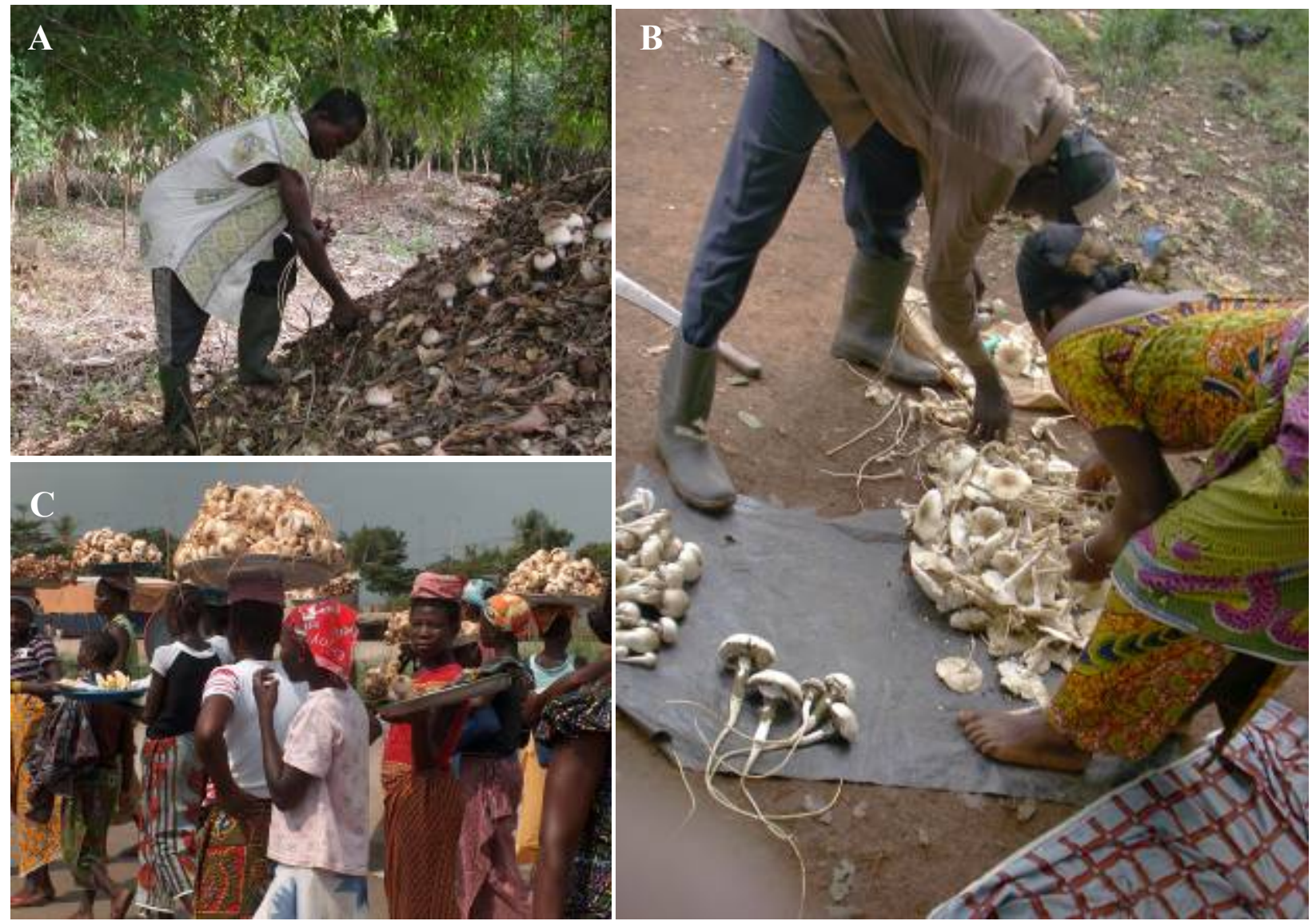

Figure 3: Actors of the harvest and trade of Termitomyces fruit bodies in central and southern Côte d'Ivoire. A: A business harvester collecting non-opened fruit bodies of Termitomyces letestui on a termite mound in the field. B: A business harvester selling his Termitomyces lestetui fruit bodies to a rural small dealer near forest patches. C: Young girls and women (rural small dealers) selling large quantities of Termitomyces fruit bodies along the northward motorway (locality of N'Zianouan).

Actors' seasonal income: Seasonal income (i.e. February to April) of actors varies significantly according to the actors' category (Table 1). The highest average earnings for business harvesters have been observed in villages located in the semi deciduous forest (US\$264.58 $\pm 5.14(\mathrm{~N}=7)$ ), while those of the Guinean savannah reach only US\$65.67 $\pm 3.4(\mathrm{~N}=4)$ (Table 1). No rural small dealer or wholesaler was observed in villages and markets of the Guinean savannah and in two villages within the semi deciduous forest. However, seasonal earnings of the business harvesters from the Guinean savannah follow the same patterns as those of actors located in the semi deciduous forest. A rural small dealer can earn US $\$ 280.8 \pm 13.97(\mathrm{~N}=23)$ on average while wholesalers earn US $\$ 341.62 \pm 12.66(\mathrm{~N}=16)$. The amount of cash incomes generated increases from the Guinean savannah to the semi deciduous forest. 
Table 1: Individual cash income from February to April of actors in Termitomyces fruit bodies exploitation in villages (in US\$).

\begin{tabular}{|c|c|c|c|c|}
\hline Areas & Villages & Business harvesters & Rural small dealers & Urban wholesalers \\
\hline \multirow[t]{5}{*}{ GS } & Oussou & - & - & - \\
\hline & Zougoussi & $60,2 \pm 3,72^{a}(n=8)$ & _ & - \\
\hline & Ahérémou 1 & $49,25 \pm 2,85^{a}(n=5)$ & _ & _- \\
\hline & Ahérémou2 & $65,67 \pm 3,4^{a}(n=4)$ & - & - \\
\hline & Singrobo & - & - & - \\
\hline \multirow[t]{7}{*}{ SDF } & Brimbo & $78,32 \pm 8,55^{b}(n=3)$ & - & - \\
\hline & Okassou & $110,54 \pm 3,84^{c}(n=3)$ & _- & - \\
\hline & Boussoukro & $201,06 \pm 14,39 \mathrm{e}(\mathrm{n}=8)$ & $239,36 \pm 12,43^{b}(n=4)$ & $302,07 \pm 8,6^{b}(n=4)$ \\
\hline & Kanga-Nianzé & $207,95 \pm 16,82^{e}(n=7)$ & $273,62 \pm 14,78^{b}(n=5)$ & $383,07 \pm 21,61^{c}(n=4)$ \\
\hline & Batéra & $264,58 \pm 5,14^{f}(n=7)$ & $362,16 \pm 21,62^{c}(n=6)$ & $435,6 \pm 7,56^{d}(n=3)$ \\
\hline & Kodimanso & $188,16 \pm 7,49^{d}(n=8)$ & $382,78 \pm 14,72^{c}(n=5)$ & $401,3 \pm 14,7^{c}(n=3)$ \\
\hline & Bodo & $136,81 \pm 9,27^{c}(n=9)$ & $146,07 \pm 6,29 a(n=3)$ & $186,06 \pm 10,8^{a}(n=2)$ \\
\hline
\end{tabular}

Abbreviations: $G S=$ Guinean savannah and SDF = semi deciduous forest. For each category of actors, values with the same letter ( $a, b, c$ d, e and $f$ ) are not significantly different at $P=0.05$ (LSD post hoc comparison). One-way ANOVA: Mann-Whitney test. Values in bold are those higher than the Guaranteed Minimum Wage Value (GMWV: US\$80.13/month in Côte d'Ivoire) during the three months of fructification period of the most abundant species of Termitomyces.

As just mentioned, no trade of Termitomyces was observed in two villages located in the Guinean savanna (Oussou and Singrobo). Termitomyces collected in these villages were used for household consumption only, since fruit bodies are not found in quantities large enough to be traded. The trade of Termitomyces fruit bodies is well developed in five of the seven villages visited in the semi deciduous forest zone: Boussoukro, Kangagnazé, Batéra, Kodimanso and Bôdô. The income of traders in these villages per fructification campaign is higher than those located within the Guinean savannah. The Locality of N'Zianouan (located in the middle of our virtual transect line) represents the most important trade centre. Huge quantities of fruit bodies accrue at this locality possessing the biggest rural market. Only small and business harvesters are represented in localities of the Guinean savannah (Zougoussi, Ahérémou I, Ahérémou II, Brimbo and Okassou) whereas representatives of all categories of actors except urban small dealers were present in five villages within the semi deciduous forests around Boussoukro, Kangagnazé, Batéra, Kodimanso and Bodo. When converting the seasonal earnings of actors into monthly incomes (fructification season lasts from February to April $=3$ months), and taking Guaranteed Minimum Wage Value (GMWV) of the country
(US\$80.13/month) as reference, Termitomyces fruit bodies provide satisfactory income for business harvesters on the one hand and great cash income for rural small dealers and the wholesalers on the other hand (values in bold in the Table 1). Monthly income of rural small dealers and wholesalers are equal or higher than the GMWV in four of the localities from the semi deciduous forest zone: Boussoukro, Kanga-Nianzé, Batéra and Kodimanso. All actors in Batéra have a monthly income higher than the GMWV. Rural small dealers use to sell fruit bodies twice the price they acquired them, since the original bunch is systematically divided in two. The same process is also generally repeated between small dealers and wholesalers. Size of the bunch of fresh fruit bodies differs among steps of the trade route. It becomes smaller with every upgraded step of the trade circuit (e.g. from business harvesters to consumers) whilst the sale price remains the same. In addition, the sale price of the bunch changes with the availability of fruit bodies. A bunch of 6 or 7 fruit bodies can move from US $\$ 0.5$ to US $\$ 1$ from the beginning to the end of the fructification season. Actors also revealed that consumers prefer closed fruit bodies. Consequently, harvesters collect the mushrooms as early as possible, before the caps (pileus) of the fruit bodies are open. 
These closed fruit bodies are judged easy to preserve and recognized to be more profitable.

Assessment of Termitomyces fruit body abundance: According to business harvesters, Termitomyces fruit bodies' production varied with the size of the termite mound. In addition, the mean number of fruit bodies per termite mound varied from a phytogeographic zone to the next (16 in the Guinean savannah and 47 in the semi deciduous forest for $\mathrm{N}=17$ and 45 interviewees respectively). Between villages located in the Guinean savannah, the number of fruit bodies collected per termite mound was not significantly different at $P=0.05$ (LSD post hoc comparison); but significant differences were observed between those around villages located in the semi deciduous forests zone (Figure 4). The highest production of fruit bodies per mound was found in the semi deciduous forests zone compared to the Guinean savannah. Consequently, the trade of fruit bodies is especially well developed in these villages (figure 4 and Table 1).

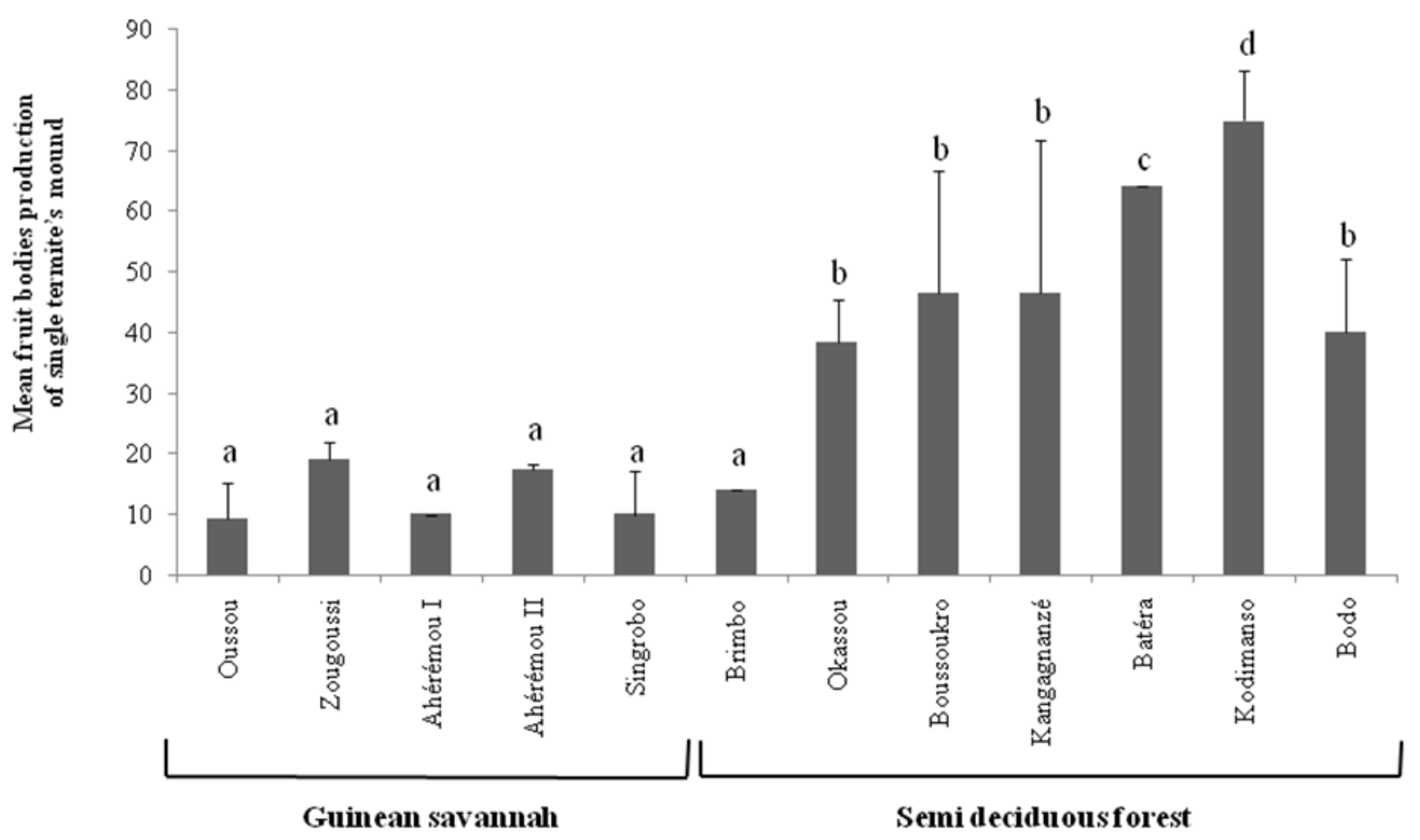

Figure 4: Mean number of fruit body's production of single termite's mound in habitats of the visited villages. Values with the same letters ( $a, b, c$ and $d$ ) are not significantly different at $P=0.05$. One-way ANOVA: Kruskal-Wallis test. $N$-numbers are those reported in the table 1.

\section{DISCUSSION}

This study results showed that only fruit bodies of Termitomyces letestui were sold. However, three additional species occur in the study area according to Koné et al. (2011), these are: T. medius, T. cf. eurhizus and $\mathrm{T}$. fuliginosus. The trading preference might be explained by (i) the abundant fructification of the species T. letestui, (ii) the high appreciation of its fruit bodies by the local people and (iii) the fact that its host termite species (Pseudacanthotermes sp) is the most abundant in the study area (Dosso et al. 2010). In addition, might the reason also be that $T$. medius and $T$. fuliginosus fruit bodies look different and the customers may not recognize them reliably (figure 1). Termitomyces cf. eurhizus looks morphologically as $\mathrm{T}$. letestui but with a dark grey color. As for T. fuliginosus and T. cf. eurhizus, fruit bodies are too rare and thus too much effort is needed to collect them in rewarding quantity as argued by Koné et al (2011). However, T. medius is a relatively abundant species but its fruit bodies are not sold. This species was not known by local people as a Termitomyces species and as an edible mushroom probably because it bears the smallest Termitomyces fruit bodies in the study area, growing up from completely subterranean termite nests. In the study area, seasonal 
exploitation of Termitomyces fruit bodies is considered as a real occupation for both farmer genders (female and male) and young girls as well, contrary to what has been observed in Malawi in Southern Africa (Morris, 1987 \& 1994) and in many countries in Central Africa, where only women and children are in charge of collecting and trading mushrooms. Termitomyces fruit bodies were found to stand alone as a meal and being used as supplement or alternative to meat or fish by rural people since they are less expensive. The big town consumers usually mixed these mushrooms with meat or fish in their daily diet, considering it a side dish only.

Phenology studies undertaken by Koné et al. (2011) in our study area proved that Termitomyces letestui fruit bodies occurred from February to April at the beginning of the rainy season, after the long drought season. At that time, all the cultivated crops from the previous season have been completely used up whilst those from the following one are not available yet. Our results confirmed that Termitomyces fruit bodies are collected and sold for subsistence purposes and represent a key source of income for rural people, especially for women (marketing) and the farmers (harvesting). Obvious is the profit for the rural people's livelihood in terms of additional income through the trade of these mushrooms. Participants in this trade gain a remarkably good monthly income (in comparison to the MGWV of Côte d'Ivoire). Termitomyces fruit bodies' trade helps farmers (i.e. the business harvesters among them) to procure their domestic needs and/or to expand their farms or to run a small shop in their village. It also allows young girls and women to (i) get capital for other crop business after the fructification period of Termitomyces and (ii) to attain their economic independence.

Trade patterns occurring in our study area differ from those reported from other West African countries. A clearly subdivided trade route in the seasonal exploitation of these mushrooms exists. In Benin for example, in spite of the high natural production of edible mushroom species in some areas, their harvest and trade remain an opportunistic activity (Yorou et al 2002). In Ghana, women and children do mushroom hunting but no wellestablished trade route exists for their seasonal exploitation (Apetorgbor et al. 2005). The differing situations observed in our research areas in Côte d'Ivoire might be explained by (1) the high abundance of Termitomyces fruit bodies in the study area, (2) the locally well developed trading network with effective links between the local, regional and national markets and (3) the high appreciation of Termitomyces fruit bodies, which are very appreciated and very much sought after as food by the Ivorians in general.

With the currently increasing deforestation and progressive fragmentation caused by shifting slash-andburn cultivation and a soaring farming intensification due to a steeply increasing human population, suitable habitats for Termitomyces are becoming scarcer and scarcer (FAO/UNEP, 1981). The thereof resulting increasing and uncontrolled harvesting pressure will have a decreasing productivity as consequence. The local people harvest the mushrooms as early and as frequently as possible, preventing the caps (pileus) of the fruit bodies from opening and the sexual spores from fully developing. This harvesting method is likely to have negative consequences for the termites. In the termiteFungus mutualistic relationship, the most common and presumably primitive mode of reproduction for the symbiotic fungus is to produce basidiocarps reaching the surface of the host termite's mound (Korb \& Aanen, 2003), during the rainy seasons and providing the next generation of termite sexuals with horizontally propagated spores. With an increasing harvesting pressure newly, founded colonies, using this transmission mode, might have difficulties to find matures spores for the successful inoculation of their combs (for more details see Korb and Aanen, 2003). Termites of the genus Pseudacanthotermes, which is the host of the widely sold fungus (T. letestui) in our study area belongs to the species using horizontal spore transfer for the maintenance of their mutualism. This study could help raising awareness for the necessity of a sustainable exploitation through adapted harvesting and protection of the habitats against agricultural practices, which are detrimental for the termites. Paying attention to some basic facets of their biology and avoiding an overharvesting of the valuable fungi secures the preservation of an important cash income source for a considerable number of rural harvesters and sellers in between the latter and the end consumers.

Assanhoun Guillaume Kouassi (Masters student of the University of Bouaké in Côte d'Ivoire), for their technical 
assistance. We also express our gratitude to Dr. Ir. Nourou S. YOROU (University of Munich, Tropical Mycology, Department Biology I, Organismic Biology, Germany) for his valuable comments and help in the improvement of this manuscript. The work was partly supported by the transnational and transdisciplinary

\section{REFERENCES}

Abbadie L., Gignoux J., Le Roux X and Lepage M. 2006. Lamto : structure, functioning and dynamics of a savanna ecosystem. Springer Verlag, New York. 412p.

Anderson A. B. 1990. Alternatives to deforestation: steps towards sustainable use of the Amazon rain forest. Columbia University Press, New York.

Apetorbgor M. M., Apetorbgor A. K., and Nutakor E. 2005. Utilization and cultivation of edible mushrooms for rural livelihood in southern Ghana. $17^{\text {th }}$ Commonwealth Forestery Conference, Colombo, Sri Lanka.

Browder J. O. 1992. The limits of estractivism: tropical forest strategies beyond extractive reserves, Biosci. 42(3), 174-182.

Buyck B. and Nzigidahera B. 1995. Ethnomycological notes from Western Burundi. Belg. Journ. Bot. 128(2) : 131-138.

Degreef J., Malaisse F., Rammeloo J. and Baudart E. 1997. Edible mushrooms of Zambezian woodland area: a nutritional and ecological approach. Biotechnol. Agron. Soc. Environ. 1: 221-231.

De Kesel A., Codja J. C. and Yorou N. S. 2002. Guide des champignons comestibles du Bénin. Cotonou, Jardin Botanique National de Belgique et CECODI : $275 \mathrm{pp}$.

Dosso K., Konaté S., Aidara D. and Linsenmair K. E. 2010. Termite diversity and Abundance across fire-induced habitat variability in a tropical moist savanna (Lamto, Central Côte d'Ivoire). Jour. of Trop. Ecol. 26: 323-334.

FAO/UNEP 1981. Tropical forest resources assessment project. FAO, Rome.

Härkönen M., Saarimäki T. In addition, Mwasumbi L. 1995. Edible mushrooms of Tanzania. Karstenia 35 (supplement): 1-92.

Koné N. A., Dosso K., Konaté S., Kouadio Y. J. and Linsenmair K. E. 2011. Environmental and biological determinants of Termitomyces species seasonal fructification in central and southern Côte d'Ivoire. Insect. Soc. 58: 371-382. project "BIOTA-West" BIOdiversity Transect Analysis in West Africa funded by the German Federal Ministry of Education and Research (BMBF, FKZ 01 LC 00617A2) and the International Foundation for Science (IFS: D/4982-1).

Korb J. and Aanen D. K. 2003. The evolution of uniparental transmission of fungal symbionts in fungus-growing termites (Macrotermitinae). Behav. Ecol. Sociobiol. 53, 65-71.

Kusters K., Ros-Tonen M. A. F., Van Den Top G. M. and Dietz T. 2001. The potential contribution of nontimber forest product extraction to tropical forest conservation and development: lessons from a case study of bamboo utilisation in Sierra Madre community, the Philippines. J. Bamboo and Rattan, Vol. 1, No. 1, pp. 77-94.

Moris B. 1987. Common mushrooms of Malawi. Fungiflora. Oslo, Norway 108pp.

Morris B. 1994. Bowa: ethnobotanical notes on the macrofungi of Malawi. In Senya J. H. and Chikuni A. C. Proceedings of the XIIIth Plenary meeting. AETFAT, Malawi. P 635-793.

Mossebo D. C., Amougou, A. and Atangana R. E. 2002. Contribution à l'étude du genre Termitomyces (Basidiomycètes) au Cameroun : écologie et systématique. Bull. Soc. Mycol. Fr., 118 (3), p. 195-249.

Pagney P. 1988. Le climat de Lamto (Côte d'Ivoire) In: Le climat de la savane de Lamto (Côte d'Ivoire) et sa place dans les climats de l'ouest africain (Lamotte M. and Tirefort J. L., eds), Trav. Cherch. Lamto. pp 31-79.

Pegler D. N. and Piearce G. D. 1980. The edible mushrooms of Zambia. Kew bulletin 35 (3): 475491.

Piearce G. D. and Sharp C. 2000. Vernacular names of Zimbabwean fungi: a preliminary checklist. Kirkia 17 (2): 219-228.

Ros-Tonen M. A. F. 2000. The role of non-timber forest products in sustainable tropical forest management. Holz als Roh- und Werkstoff 58: 196-201.

Ros-Tonen M. A. F., Dijkman W. and Lammerts van Bueren. 1995. Commercial and sustainable extraction of Non-Timber Forest Products, Towards a policy and Management oriented research strategy. The Topenbos Foundation, Wageningen. 
Thoen D., Parent G. And Lukengu T. 1973. L'usage des champignons dans le haut-Sahaba (République du Zaïre). Bull. Trim. Centr. Études Probl. Soc. Econ. (CEPSE) "Problèmes sociaux Zaïrois". 100-101: 69-85.

van Dijk H., Neree, A. O. \& Thomas, W. K., 2003. Knowledge and utilization of edible mushrooms by local populations of rain forest of South Cameroon. Royal Swedish Academy of Sciences. Ambio. Vol. 32, № 1, 19-23.

Yao K. M. 2001. Impacts environnementaux des projets de developpement sur le sol et l'eau: cas de la plantation d'ananas de la SCB (Ahérémou II, Côte d'Ivoire). Mémoire de DEA de l'Université d'Abobo-Adjamé, Côte d'Ivoire. 105p.

Yorou S. N., De Kesel A., Sinsin B. and Codja J. C. 2002. Diversité et productivité des champignons comestibles de la forêt classée de Wari-Maro (Bénin, Afrique de l'Ouest). Proceedings of XVIth AETFAT Congress, Brussels 2000. Syst. Geogr. P1 71: 613-625. 